Special Issue on Federalism and Identity edited by Michael Burgess, Soeren Keil and Sean Mueller

\title{
“DE-FEDERALISATION” VS. DEMOCRATISATION The Politicisation of Federal Reforms in Russia
}

\section{by Nadja Douglas}

Berlin Graduate School of Social Sciences, Humboldt University Berlin

Email: nadja.douglas@hu-berlin.de

Abstract: Which type of federalism can best be combined with what form of democratic system remains a puzzle in both democratisation and federalism literature. The Russian case illustrates in multiple ways that federalism does not work if democratic structures on the national and regional level are dysfunctional. The aim of this article is two-fold: first, it aims to delineate how federal reforms in Russia during the last decade have led, through politicisation, to a process of de-federalisation rather than to the construction of a strong federal system in the country. Second, by means of analysing selected federal reforms, the question will be explored whether the process of de-federalisation has correlated with, if not contributed to, the dismantling of democratic elements in the country. In sum, this article seeks to make a case for the continued combination of federalism and democracy studies in order to advance theory-building in the application to specific regional contexts.

Keywords: Russia, de-federalisation, democratisation

Douglas, N. (2013), "De-federalisation" vs. democratisation: The Politicisation of Federal Reforms in Russia, Federal Governance, vol. 10, no. 2, pp. 19-34. 


\section{About Federal Governance}

Federal Governance is an online graduate journal on theory and politics of federalism and multilevel governance. Its mandate is to engage the global federalism community and reach out to outstanding graduate students interested in federalism and multi-level governance. By providing a platform for graduate students to have early success in their careers, Federal Governance seeks to promote and sustain interest in federalism and multi-level governance research among graduate students. Allied with the Forum of Federations and founding partner, Institute of Intergovernmental Relations at Queen's University; Federal Governance aims to contribute to a global dialogue on federalism.

Co Chairs, Advisory Committee:

Publisher:

Managing Editor:

Associate Editors:
Rupak Chattopadhyay and Christian Leuprecht

Forum of Federations

(Rupak Chattopadhyay and Philip Gonzalez)

Dominic Heinz

Maria Bertel, Carey Doberstein, Sean Mueller, Eyene

Okpanachi and Samir Sharma

\section{Terms of Use}

Your use of this Federal Governance article indicates your acceptance of Federal Governance's Terms and Conditions of Use, available at www.federalgovernance.ca/terms. Federal Governance's Terms and Conditions of Use provides that you may use Federal Governance content only for personal, academic and non-commercial use. Each copy of any part of this Federal Governance article must contain the same copyright notice that appears on the screen or printed page of such transmission. 


\section{Introduction}

Although Russia is considered a de jure federation which, in accordance with the constitution, relies on territorial self-rule combined with shared rule between the Federation and its subjects, federal elements have de facto been gradually reduced or modified in a rather indiscriminate manner in recent years. The policy of re-centralisation, expressed in a number of federal reforms introduced by Vladimir Putin since 2000 , has essentially been maintained during the Medvedev years except for a few reform reversals as concession to protests in the aftermath of the disputed parliamentary and presidential elections in 2011/2012. Back in presidency, Putin formally underlined the need for de-centralisation at the end of 2012 (Petrov, Carnegie Centre, 17 December 2012). However, recent legislative bills passed by the State Duma rather seem to confirm the centralising trend of the past years. Politically, this policy serves the purpose of rationalising administrative structures, enhancing regional economic development and, last but not least, increasing national unity. Most importantly, however, it continues to secure and strengthen the existing power vertical. Despite a general awareness of the need for de-centralisation, the concept that could be termed "politically centralised federalism" has found entrance also into the Russian academic debate and is likely to remain the guiding policy in the years to come.

This article seeks to illustrate how federal reforms in Russia during the last decade have led to a process of "de-federalisation" rather than to the construction of a strong federal system in the country. Another aim is to show how federal reforms continue to be politicised as correctives for solving other, allegedly more pressing, political problems. The main question to be explored here is whether the reverse correlation between "de-federalisation" and "de-democratisation" holds true, in other words whether unconstitutional federal reforms contribute to a further dismantling of democratic structures in Russia ${ }^{1}$. In the following, selected federal reforms will be examined, first in light of their underlying (political) objectives and second in terms of their constitutionality. Constitutionality (konstituzionnost') is understood here as the compliance between constitutional norms and constitutional reality.

Starting point for the analysis is the federalism-democracy debate (see for example Benz 2003; 2009; Ross 2007; Stepan 2009; Burgess/Gagnon 2010; with particular emphasis on transitioning states Filippov/Shvetsova 2011), which remains a very contested one since the problem of causality between federalism and democracy still lacks theorisation. For a long time, there was a widely spread assumption that federal and democratic progress are mutually conducive. However, this argument, as will be shown in the next section, has been discarded by several authors as it does not take into consideration the complexity of the relationship and oftentimes very diverging regional contexts.

Unfortunately, the Western and Russian debate on the topic run somewhat parallel and independent from each other. This is why aspects of the Russian academic debate on the state of Russian federalism will be included here in order to provide a more coherent picture. Taking into

\footnotetext{
1 The aim of this article is not to discuss whether the Russian Federation has ever been a democratic state or to what degree it can be considered an authoritarian one today. The interest lies more in the identification and analysis of current trends that affect the organising principles of the state and impact on further political decision-making.
} 
account the Russian perception of the interaction between the federal state structure and the political system, one arrives at a quite divergent (from the Western) understanding of what progress, strategic modernisation and development of a political regime mean. Whereas from a Western perspective, federal and democratic progress can be achieved by strengthening the rule of law, democratic institutions, pluralism as well as civil society structures, in the Russian debate the picture of a modern federal state is shaped rather by the idea of a strong, centralist, politically efficient, territorially integrated and above all socio-economically developing state with other challenges to be tackled only at a future moment.

\section{The Federalism-Democracy Debate}

Analysts that deal with transitioning states occasionally bring forward the argument that democracy and federalism are contingent upon each other. That may also be the reason why federal political systems have often been recommended for post-war or multi-national societies. They are supposed to accommodate and compensate for, or even eliminate, internal diversities and tensions in the process of federal bargaining. Federalism in this context has been regarded as a strategy to foster democracy (Watts 2010: 327-344). In his seminal work "Comparing Federal Systems", Watts describes how democratic and federal structures and values are conducive to one another:

[...] liberal-democratic values are a precondition for an effective federal political system that depends upon the respect for constitutional norms and the rule of law, respect for regional minorities, and a spirit of tolerance and compromise. Federalism in turn [...] enhances liberaldemocratic values by ensuring democratic legitimacy of both the federal and the constituent unit governments, each directly elected by and accountable to its own electorate, and by checking autocracy through the dispersal of legitimate power among multiple centers of decision making within the polity. (Watts 2008: 192)

According to this type of normative theory of federalism, it should be unequivocal that federalism enhances democratic development since it ensures power-sharing, pluralism, accountability, mutual control and thus democratic legitimacy. Benz (2003; 2009) has reviewed the potential benefits of federalism for democracy and argues that this compatibility vision, notwithstanding all its merits, turns out to be rather undifferentiated. Benz states that the link between federalism and democracy is much more complex and that the existing terminology both in democracy research as well as federalism theories barely takes into consideration the variability of either federalism or democracy (Benz 2003: 10-11). He especially emphasises that both fields of research associate different notions of democracy that vary between individualistic and collectivistic understandings of the "demos" to respective notions of federalism (ibid.). Here one has to differentiate in terms of terminology between democracy as a type of political system and democracy as democratic legitimation in terms of a criterion for the evaluation of a political system (ibid. $f n 5$ ).

The synergy between federalism and democracy has been challenged already during the 1990s, when the assumption was advanced more frequently that federalism could prove to be more of an obstacle to the process of democratisation, especially in those states where democratic structures had not yet been consolidated (see for example Linz/Stepan 1996 and Snyder 2000). Indeed, in 
the young Russian Federation, during the 1990s, a tendency toward national democratisation was observed, while on the subnational level extremely authoritarian regimes emerged from the ethnically defined republics and autonomous regions. Thus, the retention of the inherited model of Soviet "ethno-federalism" inhibited the democratisation processes in the republics (HeinemannGrüder 2009: 73). Accordingly, it is argued that federalism, by accommodating regional diversities, identities and ethnicities, can even contribute to an aggravation of ethnic and societal conflicts to the point of facilitating open secession (Bunce/Watts 2005). Fillipov and Shvetsova conclude that only in well-functioning democracies can federalism develop into a stable and effective form of government. They argue that, in the short run, the federal form with its additional challenges could push political leaders to interfere with the democratic political process. Therefore, Fillipov and Shvetsova maintain the argument that in low-functioning or newly established democracies the federal structure would inhibit democratic development (Fillipov/Shvetsova 2011: 4). These authors, who can be considered Western since they are both affiliated with U.S. universities, are partially in agreement with Russian scholars who tend to argue that (re-)centralisation or defederalisation during a transition period would be inevitable in order to then again concentrate on democratic progress.

Among Russian scholars in the field, the assumption is widespread that President Putin's "centralist version of federal development" prevented the disintegration of the country (see for example Bekbosynov 2011: 9). Weak, politically decentralised structures of power would be, according to Bekbosynov, a source of serious problems, especially for countries in transition (2011: 296). Thus, the vision of future Russian federalism yields into the concept of a "politically centralised and bureaucratically decentralised territorial federalism". Here, the main political directives and policies would be decided in the centre and bureaucratic and executive procedures were to be the responsibility of the regions (Bekbosynov 2011:41). Of course, the debate in Russia is not one-sided; a number of authors are in favour of "re-de-centralisation" (see for example Gribanova 2007, Klistorin 2011, Zakharov 2012). There are also positions that emphasize the link between federalism and democracy, explicating that a reintroduction of democratisation attempts would lead to a rebirth of federalism in Russia (Kovalev 2007:253). A metaphorical description of the state of federalism in Russia during the last decade is provided by Zakharov, who describes Russian federalism as a "sleeping institute", whose existence has neither been called to mind by Russian politicians nor scholars (Zakharov 2012:103). He emphasises, however, that the present authoritarian regime cannot simply abolish federalism, since federalism is needed by the national minorities that make up about 20 per cent of the population of the country. The federal institutions in a state of "hibernation" will, according to Zakharov, inevitably wake up at some point without state officials being prepared for it (2012: 124). ${ }^{2}$

The concept of a "politically centralised federalism" or, similar to it, of so-called "executive federalism" can however be seen as problematic. As Heinemann-Grüder notes, these views do not prove that centralism is a guarantee of the rule of law and stability (Heinemann-Grüder 2009: 59). In short, if no regard is paid anymore to the vertical separation of powers, it is likely that the horizontal separation of powers (e.g. judicial independence) will also suffer. Moreover, these

\footnotetext{
${ }^{2}$ This brief literature overview does not claim and is not intended to be exhaustive. It does not reflect the entire Russian debate on the topic, but rather echoes a few opinions.
} 
concepts dismiss the fact that federalism, by means of its multiple bargaining processes, dissemination of political power, and the creation of accountability mechanisms on various levels, can itself contribute to the consolidation and stabilisation of rule of law principles and thus of the political regime itself.

With reference to the federalism-democracy debate the task of this article is to explore whether, on the contrary, the reverse question of a correlation between unconstitutional federal reforms and the dismantling of democracy holds true. "Democracy" and "federalism" as concepts have been defined extensively. However, their antonyms, relevant for this article, need further elucidation. Defederalisation is a concept predominantly found in the Anglo-American and German literature (for an application to the Russian example see for example Ross 2007, Heinemann-Grüder 2009, Sakwa 2010). It implies the phenomenon of increasing centralisation of the political order by means of concomitant centripetal tendencies. However, this does not concern unification tendencies in a unitarian sense, since the federal framework is formally maintained but gradually loses its significance. Unlike mere centralisation, de-federalisation involves a federal reform process that is not constitutionally anchored, thus putting at stake fundamental federalist principles. In other words, de-federalisation implies centralisation as well as concomitant political processes such as the instrumentalisation of federalism for the realisation of other goals, thereby undermining the existing federal system instead of strengthening it.

Although not termed that way, the phenomenon has also been described by Russian scholars who note that the formal attributes of a federation have been retained in Russia (federal subjects keep their distinct territory, capital, flag, hymn, independent constitution, legislative assembly, executive and judiciary), while the evolution of the federal state structure has gone at the expense of competences of the federal subjects and their degradation to mere administrative-territorial unities (see Mindzaev 2011:26 and Kovalev 2007:236).

De-democratisation, by contrast, is understood as a degeneration of democratic institutions, norms and culture, for which various factors can be held responsible, ${ }^{3}$ among others de-federalisation. This is a process that is notably determined by the failure to consolidate federal structures (and instead gradually dismantle them), which will be described in more detail in the following section

\section{The Failed Consolidation of Federalism}

The re-centralisation of competences in Russia to the detriment of regional self-rule began in 2000 with the appointment of presidential envoys in seven newly created federal districts. Other measures included the reform of the Federation Council. Instead of regional executive leaders or governors who used to be members of the upper chamber of the Russian Federal Assembly, it was decided that one representative of each regional executive as well as legislature would get a seat in the Federation Council. The modality of constituting the Federation Council has ever since been

\footnotetext{
3 The term is used also in other contexts. Critical globalisation studies refer to "de-democratisation" in the debate on globalisation as a major factor for the degeneration of democracy. Emerging democratic deficits in the development of supra-national entities like the European Union have been described as "de-democratisation". Furthermore, the term has been used more generally to identify decreases of democratic quality on the national level.
} 
called into question. Between 2004 and 2012, governors were not elected anymore by popular elections but nominated by the President. The practice and legitimacy of appointed governors appointing members of the Federation Council has been contested (see Gribanova 2007: 198). Gribanova for example points out that it was not by accident that the European Commission in 2004, when the federal reform on abolishing gubernatorial elections was introduced, evaluated the situation of the Federation Council as most threatening to the democratic development of Russia (2007: 198).

In relevant Western literature, the disempowerment of the Federation Council and the concentration of powers in the presidential administration were considered to be structurally hostile to federalism. Indeed, the greatest challenges to Russian federalism do not lie anymore in the threat of secession or ethnic disintegration but, according to Ross, in the danger of defederalisation and centralisation (2007: 109). Ross lists four factors that would thwart the consolidation of federalism in Russia:

1. High levels of socio-economic, constitutional and political asymmetry;

2. Conflict between the contradictory provisions of the regional constitutions/statutes and the national constitution;

3. The problematic legacy of ethno-federal structures bequeathed from the USSR upon the Russian Federation; and

4. The violation of federal and democratic principles.

Regarding the first factor, it must be noted that socio-economic asymmetries in particular are an inherent problem of Russian federalism. The regional differences in gross regional product per capita are decreasing, but still vary by a factor of 19 (see Rosstat for the difference in GRP between Tyumenskaya Oblast' and Republic of Ingushetia in 2010, Moscow excluded for being responsible for the bulk of Russia's GDP). This is aggravated by the fact that rich donor regions are still more successful in obtaining political autonomy in the bargaining process with the centre than poor recipient regions that are completely dependent on federal transfers for their economic survival (for more information on fiscal autonomy for subnational regions see Deryugin/Kurylandskaya 2007: 260).

As for the constitutional and political asymmetries, they can be ascribed to the dual character of the Russian Federation, which grants different rights to different federal subjects. Although the Russian constitution, in its Article 5, declares all federal subjects to be equal, some ethnic republics do have more rights than other territorially defined subjects (Ross 2007: 111). As a result, these diverse political asymmetries and the republics' opportunity to decide relatively freely on their political structures have led to the emergence of quite different subnational political regimes within Russia.

Every federation relies on a voluntary union or a social contract which implies the adoption of a constitution. Elaborating on the aspect of contradicting constitutions (2), Ross states that in Russia the constitution was imposed on the country from above by former President Yeltsin, who had to acknowledge very soon that 19 of the 21 republican constitutions were in breach of the federal constitution (2007: 114). As a result, it came to an inflationary conclusion of bilateral treaties 
between the centre and the regions that regulated the delimitation of competences and thereby coined the term "treaty federalism", a phenomenon that was mostly reversed under Putin.

As for the Soviet ethnofederal legacy (3), some authors state that the official conception of Russian federalism has partly inherited and returned to a "Soviet fig-leaf type of federalism - which acts as a symbolic reminiscence for those groups, which are not yet fully assimilated" (Heinemann-Grüder 2009: 58). Groups and associations that represent the rights of indigenous people, such as the "Russian Association of Indigenous Peoples of the North" (RAIPON), are legally considered nongovernmental organisations. They do not only face the problem that they cannot raise their voice within the federal framework, but they are also confronted with repression from authorities similar to other civil society organisations. RAIPON had to suspend its activities in November 2012 due to non-compliance of its statute with Russian legislation. The violation of federal and democratic principles (4), finally, is another factor in the process of strengthening the power vertical. The Russian President has been demanding increasing accountability by regional governors and other functionaries towards the executive, which however goes at the detriment of provincial responsibilities. Also, the reciprocal accountability of the central government to the regions has increasingly been substituted by state subsidies and material incentives, which make the system of governance more susceptible to crises.

\section{Implications of Federal Reforms}

As stated above, the federal reform process under Putin started right at the beginning of his Presidency in 2000 with the introduction of new federal districts and the appointment of presidential envoys. The reform process continued with the repeated modification of the Law on Political Parties that proved to have federal implications. It cumulated in the abolition of the direct popular election of governors in 2004. In particular, this reform was contested in Russia and criticized by foreign experts. When direct gubernatorial elections were partly reinstalled by Medvedev in 2012, it was believed to be a rare democratic boost. However, a new legislative bill in January 2013 stipulated that the direct election of governors would henceforth be facultative, in other words it should be open to regional assemblies whether they wanted to keep the direct election of governors or not. Finally, the reform of merging small ethnically defined federal districts with adjacent territorial federal subjects (ukrupnenie) started in 2003, was stalled in 2007, but is said to continue until the federal-territorial rationalisation has been achieved.

\section{Introduction of new federal districts and presidential envoys}

The introduction of seven (now eight ${ }^{4}$ ) federal districts was accompanied by the establishment of a number of institutions that were not foreseen by the constitution and were not conceived to consolidate federal structures either. Petrov speaks of the "security dimension of the federal reforms" and states several important facts: (1) the seven federal districts correspond exactly to the

\footnotetext{
${ }^{4}$ The North Caucasian Federal District became the eighth federal district in January 2010. It was separated from the Southern Federal District in order to increase governability and control on the volatile Caucasian federal subjects.
} 
districts of the Internal Troops of the Ministry of Internal Affairs (MVD); (2) the presidential plenipotentiaries ("Polpreds") in those districts became at the same time members of the national Security Council, which in 2000-2001 was made up of top politicians and heads of the key "power ministries" (silovye vedomstva); (3) a significant proportion of those chosen as chief federal inspectors (CFIs) for the regions were recruited from the regional siloviki, mainly chiefs of the regional power ministries; (4) the power ministries (except for the Federal Security Service [FSB]) created parallel structures at the new district level, their staff often outnumbering those of the presidential plenipotentiaries; and (5) one year after the reform had begun, the heads of the largest power ministries - defence and internal affairs - were replaced, and after another three years the structure of the remaining power ministries was radically altered and the FSB greatly strengthened (Petrov 2005: 7-8).

Petrov implies here that the connections between the modification of power and security structures and federal reforms, notably the introduction of the federal districts, were not a coincidence, but intended and multi-dimensional. According to Petrov, the federal reforms and the restructuring of the security agencies were different manifestations of one and the same effort to modify the structure of authority and power within the Russian Federation (Petrov 2005: 8). Essentially, he regards the parallelism of federal reforms and institutional reorganisation as a strategic endeavour to make society more governable by means of a setting up an effective system of supervision and control (Petrov 2005: 13). While not per se "de-federalisation", this represents an example of utilisation of federal reforms for the realisation of a changed institutional set-up that has the sole purpose of strengthening the vertical power. This can be regarded as politicisation of federal reforms for other purposes than developing the federal system. The centralisation process together with the eventual erosion and dismantling of the federal system are referred to as "defederalisation".

Indeed, democratic institutions are not only weakened but actually replaced by "proxy institutions" that resemble federal institutions in their function, but which are ultimately created to form an intermediate administrative level between central and regional authorities and thus integrate and increase control mechanisms The apparatus of the presidential plenipotentiaries and CFIs are not constitutionally anchored and accountable only to the President. The "advantage" of this type of proxy institution is that it can be abolished as quickly as it was established - by presidential decree. It is self-evident that the creation of this intermediate administrative level has not only fostered de-federalisation by undermining the role and function of the Federation Council as the voice of the regions and substituting its reporting mechanisms with the apparatus of the plenipotentiaries. It has also greatly contributed to the consolidation of power structures on the vertical level by levering subsidiarity and de-centralised decision-making mechanisms and on the horizontal level through further blurring the separation of powers.

\section{The "Federal Law on Political Parties"}

Detailed regulation on the formation and registration of political parties can be found in the "Federal Law on Political Parties" of 2001. Major amendments in the following years severely exacerbated the creation and registration of new parties. They stipulated for example that a party had to be registered with a minimum of 500 members (as opposed to 100 members in the original version of 
the law) in at least half of the 83 federal subjects and have a minimum of 50,000 party members in total (as opposed to 10.000 members before). Furthermore, the original threshold of 5 per cent for entering parliament was raised to 7 per cent (Nußberger/Marenkov 2007: 3).

Another important amendment stipulated that the "creation of political parties on a professional, racial, national or religious basis" was no longer permitted (Article 9, 3). With this prohibition, the political representation and freedom of expression of minorities in the regions were considerably weakened. In the course of this party prohibition, many parties - both on the national and regional level - were forced to dissolve. In a 2011 ruling, the European Court of Human Rights criticised the law following a complaint concerning the dissolution of the Russian Republican Party. The Court ruled in favour of the plaintiff. It underlined that the frequently amended Law on Political Parties made it all but impossible for small minority groups to establish political parties and participate in elections. The Court further disagreed with the argument of the Russian government that only those associations that represent the interests of considerable portions of society are eligible for political party status. It argued in favour of a balance that must be achieved between fair treatment of minorities and the prevention of abuse of dominant positions (c.f. case of Republican Party of Russia v. Russia, final judgement, ECHR, April 2011).

In the aftermath of the ECHR decision and as yet another concession to mass protests in 2012, Medvedev initiated another change of the law by withdrawing restrictions. Thus, the number of members required for registration was reduced to 500 , while the number of 42 necessary regional branches was maintained. The registration process was shortened altogether. As a result, according the Ministry of Justice, there are currently around 195 political parties that have applied for registration. While on first glance this proliferation of parties seems to confirm a more pluralistic party system, analysts fear many parties to be artificially created structures that are supposed to take away votes from real oppositional parties (Winogradow/Ostaptschuk, Deutsche Welle, February 2013).

The reform process regarding the law on political parties is to be seen as yet another attempt to centralise political structures. The fact that electoral blocs (mergers of several parties) have also not been eligible in recent years hampers the emergence of a real pluralist multi-level party system and ultimately undermines the concept of federalism, according to which minorities should be included in the political decision-making process at the federal level (cf. Nußberger/Marenkov 2007:3). Considering the importance of a de-centralised party system for the consolidation of federalism, Elazar in his seminal work "Exploring Federalism" argues:

The existence of a non-centralized party system is perhaps the most important single element in the maintenance of federal non-centralization. Non-centralized parties initially develop because of the constitutional arrangements of the federal compact, but once they have come into existence, they tend to be self-perpetuating and to function as decentralizing forces in their own right. (Elazar 1987:178)

The current dominant political party, Edinaya Rossiya (for a detailed analysis of dominant party regimes and the case of United Russia see for example Konitzer/Wegren 2006 and Reuter/Remington 2009), has managed to fully penetrate the periphery of the country. Its activists recruit regional cadres, which are then directed from Moscow, thus contributing to the centralisation of the ruling party. Until 2007, many of the candidates at the regional level were independent and 
did not represent any party, but drew on social and political networks from Soviet times. This situation has changed insofar as the ruling party has now extended its presence in the regions massively. Moreover, it represents an equilibrium arrangement between the federal centre and other political and economic elite in the regions (Reuter/Remington 2009: 507/508). Many of the candidates of Edinaya Rossiya (today most regional governors are members of the Kremlin party) have a stronger party affiliation than allegiance to the region they represent. In sum, the centralisation of the ruling party and the concomitant process of marginalising all other parties thwart all aspirations towards pluralism and real electoral choice for the citizens.

\section{Abolition of popular elections of governors}

Article 3,1 of the Russian Constitution states that the multinational people are "the bearer of sovereignty and the only source of power in the Russian Federation". Yet, the sovereign people in the regions have effectively been deprived of their right to self-determination and the direct elections of their regional leaders. Between 2004 and 2012, governors were nominated by the president and elected by regional legislatives. By the end of 2011, a reform reversal regarding the return to direct gubernatorial elections was proposed by Medvedev while making concessions to demands made by popular protests. However, there were certain provisions: the so-called "presidential filter" (political parties must consult with the president before nominating candidates for the post of governor) and the "municipal filter" (candidates are required to collect the signatures of 5 to 10 per cent of municipal deputies before being allowed to take part in elections). Petrov notes that the Kremlin still appointed new governors (thus reducing the number of regions that would hold elections in autumn that year) even after the bill had been sent to the Duma. He suggested that it is still not understood that direct elections are not a concession to the opposition but a prerequisite for the survival of the political system (Petrov, Moscow Times, April 2012).

In a rather indiscriminate way a new legislative bill was passed by the Duma in January and signed by Putin in the beginning of April 2013. It now gives regional assemblies the right to abolish direct gubernatorial elections if they wish to. One of the reasons could be to forestall the aggravation of ethnic tensions caused by free gubernatorial elections in ethnic republics. In regions that renounce on direct elections, the President would again, after having consulted with political parties, present a list of three candidates to regional legislators who would then nominate one (Kommersant', January 2013). ${ }^{5}$ A number of oppositional deputies expressed their disapproval that this bill was extended to all federal subjects only because of a restricted number of problematic regions. Others feared that the Kremlin in order to hold onto power could start inciting the abolition of direct elections in regions where the governor had proved to be unpopular (Earle, Moscow Times, January 2013). This reversal of the reversal of the federal reform shows the discretionary way in which federal reforms are politicised in order to realize other objectives, such as appease oppositional protests or prevent ethnic upheaval in the Caucasian republics.

The 2004 reform has moreover proven to be in violation of the Federal Constitution, as Luchterhandt (2005) explains. The proponents of the reform referred to Article 77, 2 of the

\footnotetext{
${ }^{5}$ So far Dagestan and Ingushetia have decided against direct elections, but other multinational federal subjects could follow.
} 
Constitution which states that the federal and regional executive organs constitute a "single system of executive power". However, the "single system of executive power" does not refer to the creation of regional executive organs (which according to Article 77, 1 should occur "independently"), but only to the function and fulfilment of their objective tasks. This holds true for those fields of competence for which the federation is responsible exclusively (Article 71) or jointly with the subjects of the federation (Article 72). The unity of the system of executive power, therefore, has no organisational but only a functional character and thus cannot extend to the creation of the organs, as Luchterhandt underlines (2005: 103). Furthermore, in one of the fundamental norms of the Federal Constitution (Article 11, 2), it is declared that "the state power in the subjects of the Russian Federation shall be exercised by the bodies of state authority created by them". Hence, the competence to create organs of state authority also includes, logically, the competence of these organs of the subjects to constitute themselves. This competence is executed by the subjects of the federation independently (Luchterhandt 2005: 103). Luchterhandt concludes that if the authors of the Russian constitution had wanted to grant to the federal President the same powers concerning the formation of the regional executive vis-à-vis the regional parliaments as they have granted the President vis-à-vis the Duma according to Articles 83, 84, 111 and 117, then

the Federal Constitution should have explicitly authorised the President to do so (Luchterhandt 2005: 104-105).

This federal reform is seen by Russian scholars as a process of "regional de-politisation" (Kovalev 2007: 240). According to another author, de facto federalism can only be achieved once governors are not any longer seen as the "hosts" of their territories, restricted only by federal interests, but as political institutions that follow the call to reconcile both national and regional interests (Kynev 2010: 133). So this example not only shows how unequivocal discrepancies between the constitutional text and conceived policies are tolerated to achieve certain political goals, but also how federal reforms have been politicized in the name of national security, notably in the aftermath of the Beslan massacre in 2004, in order to stabilize political power (thus taking hostage all other federal subjects not affected by terrorism or ethnic unrest).

\section{Merger of federal okrugs}

In 2005, the federal centre started a process of further rationalisation of the federal structure by promoting territorial mergers (ukrupnenie) and the elimination of federal subjects. Since then, five regional mergers have taken place (see Table 1 in the annex). Each has involved combining or absorbing regions with sizeable ethnic groups but small overall populations into adjacent larger ones. There were two principal official explanations for the need for merging: 1) improvement of the economic situation in less developed regions (this represents the main indicator for strain in centre-region relations); and 2) maintaining administrative efficiency and stability in centre-regional relations.

Analysts of the merger process, however, hold that the underlying objective of this reform has been the plan to impose an "applied nationality policy" (see Derrick 2009: 3). Through this policy, the assimilation of national minorities would be enforced and prior freedoms granted to ethnic autonomies rescinded. According to Oversloot (2009: 119), this policy of the Russian Federation runs counter to what appears to be a trend in many other countries where indigenous peoples are 
accorded special rights and protection together with various forms of self-rule, often within their "home territories". Despite the Russian Federation having signed conventions such as the Council of Europe Charter for Regional or Minority Languages of 1992 or the Framework Convention for the Protection of National Minorities of 1995, national and linguistic minorities enjoy fewer rights today than during the 1990s. The federal merger process has provided a template for how to eliminate forms of local participation in political decision-making. Moreover, all those federal okrugs that were unified with other federal subjects lost their representatives in the Federation Council, which is less of political but huge symbolic significance.

The Russian Constitution foresees and guarantees the protection of minorities (Art. 71c, 72b) but the political reality, especially in autonomous okrugs, is a different one. Official referendums were organized prior to the merger projects, however as local observers testified, the overwhelmingly affirmative results left doubts. Protests and efforts to resist the mergers were ignored. Often the governors of the okrugs were decisive in promoting the merger. As stated above, the party affiliation of some governors with Edinaya Rossiya is often stronger than allegiance to the region they represent. A striking example is the former governor of the Buryat autonomous okrug UstOrdinski and member of Edinaya Rossiya, Valery Maleev. He agreed to the merger of his region with the adjacent Irkutsk Oblast. This merger was presented to the inhabitants of Ust-Ordinski as a profitable and progressive step, but in the aftermath it brought them mainly disadvantages (locals lost their jobs due to the closure of the municipal administration, projects to restore facilities were stalled and the general impression was that the region lost most of the subsidies that it used to receive due to its okrug status). Maleev, by contrast, was rewarded for the loss of his office and offered a post as deputy in the national Duma instead (interview by the author with local inhabitants of the former autonomous okrug, Ust-Ordinski, July 2011).

Notwithstanding this, the federal merger process has been evaluated rather positively by Russian analysts. Kolmogorova for example states that the unification of regions would represent a way out of the concept of ethnic federalism and thus a step towards a more democratic variant of the federal state structure. The "ethnic past", as she calls it, should be considered a threat to the Russian federal system in times of an instable economic and political situation (Kolmogorova 2010:157).

\section{Conclusion: Perspectives for Russian Federalism}

As stated above, Russia is de jure still a federation. On the occasion of public events or celebrations as well as in the national press, attention is paid to the use of correct federal terminology. Since the beginning of the federal reform process in 2000 , there has been hardly any dismissal of or dissociation from federalism as the model of political order, neither from the official side nor from academia. On the contrary, the weakening of the regions was considered and presented as a boost to federalism and democracy. This can partly be explained by the negative experiences during the Yeltsin years. As result of the co-optation of regional elites, according to Chepikova and Leiße "a federalism without federalists has emerged in Russia [...] a federalism that 
mistakes the federalist subjects as regional branches of the centre and executive bodies of the Kremlin" (Chepikova, Leiße 2010: 25).

The risk thus increases that in the course of further de-federalisation, people will become even more alienated from regional politics, which in turn could expedite the impairment of democratic culture in the Russian Federation. Since neither the central government nor the dominant political parties are fervent advocates of the federal idea, the current discrepancy in the Russian system between formally maintained federal institutions, on the one hand, and the erosion of the understanding of their significance and impact by means of a deficient federal culture, on the other, will be exacerbated. This can have fatal consequences, according to Heinemann-Grüder, since formal institutions always have to be backed by complementary norms and values (2007: 135).

The continuous alternation between re-centralisation and de-centralisation follows a pattern through history that is traced concisely by Gelman. Behind processes of "federal bargaining" that began under the Bolsheviks and repeated themselves every time the country suffered from upheavals, the fear that secessionist movements would prevail and eventually lead to the collapse of the state dominated most political action. Thus, a policy of de-centralisation was periodically followed by a policy of re-centralisation, always depending on the reaction of the regions, that is whether they were compliant or whether it was necessary to grant them concessions. According to Gelman, de-centralisation processes in the 1990s as well as the re-centralisation after 2000 are path-dependent (2009: 2). In this interpretation federalism is reduced to a mere functionalist concession to rebellious ethnic elites. This insight can now be extended to today's situation. As the preceding analysis has illustrated, federal reforms or reversals of reforms are again instrumentalised to appease political opposition (protesting middle classes) in the country. In sum, it can be concluded that short-term objectives of the analysed federal reforms have been realized, while long-term objectives remain unclear.

With reference to the federalism-democracy debate, it should have become clear by now that it is difficult to argue that certain manifestations or criteria of a federal system would enhance the development of democratic structures (as often done by Western transitologists). Neither does the argument convince that, once democratic prerequisites are present, building federalism will become possible by default (as Russian scholars tend to assume). The Russian example has shown that both notions of federal and democratic progress can imply very different things, depending among others very much on context and perspective.

The article has confirmed the need for a further integration of insights from both democracy and federalism studies, especially in the context of young political regimes. The case of a correlation between the manifestations of the antonyms of federalisation and democratisation may not directly contribute to the "federalism-democracy debate". Nonetheless, it may lead to a better understanding of how these processes affect organising principles of the state and political decision-making in countries like Russia that have long been considered emerging federal democracies. While it was not the goal of this article to discuss the democratisation of the Russian Federation as such, what has clearly emerged from the observations put forth here is that the elements of democracy that were achieved before the various federal reforms have gradually been put at stake by these reforms. 


\section{References}

Secondary

BENZ, A. (2003) Föderalismus und Demokratie. Eine Untersuchung zum Zusammenwirken zweier Verfassungs-prinzipien" POLIS No. 57: http://www.fernuni-hagen.de/imperia/md/content/politik-wissenschaft/ polis57.pdf

---. (2009) Ein gordischer Knoten für die Politikwissenschaft? - Zur Vereinbarkeit von Föderalismus und Demokratie. Politische Vierteljahresschrift, 50 (1): 3-22.

BEKBOSYNOV, M. B. (2011) Rossiiskii Federalizm: Dilemmy politicheskogo Vybora. Moskva, People's Friendship University of Russia.

BUNCE, V. \& WATTS, S. (2005) Managing Diversity and Sustaining Democracy: Ethnofederal versus Unitary States in the Postcommunist World. In: ROEDER, P. G. \& ROTHCHILD, D. S. Sustainable peace: power and democracy after civil wars. Ithaca, N.Y., Cornell University Press.: 133-158.

CHEPIKOVA, K. \& LEISSE, O. (2010) Russlands Simulierter Föderalismus. Regionalpolitik unter Putin und Medvedev. OSTEUROPA. Vol. 60.1: 15-26.

DERYUGIN, A. \& KURLYANDSKAYA, G. (2007) The Russian Federation in: SHAH, A. The practice of fiscal federalism: comparative perspectives. Montréal, Published for Forum of Federations = Forum des fédérations by McGill-Queen's University Press.: 236-261.

DERRICK, M. (2009) The Merging of Russia's Regions as Applied Nationality Policy: A Suggested Rationale. Caucasian Review of International Affairs. Vol. 3 (3): 317-323.

DOUGLAS, N. (2011) Interview with local inhabitants of the former autonomous okrug, UstOrdinski, July 2011

ELAZAR, D. J. (1987). Exploring Federalism. Tuscaloosa, AL. University of Alabama Press.

FILIPPOV, M. \& SHVETSOVA, O. (2011) Federalism, Democracy, and Democratization. Unpublished manuscript, http://government.arts.cornell.edu/assets/psac/sp11/Shvetsova_PSAC_Feb11.pdf

GELMAN, V. (2009) Leviathan's return: the policy of recentralisation in contemporary Russia in: ROSS, C. \& CAMPBELL, A. Federalism and Local Politics in Russia. London; New York: Routledge: 1-25.

GRIBANOVA, G. I. (2007). Federalizm i Demokratiya v Sovremennoi Rossii. In: KRASIN, Y. A. \& FARUKSHIN, M. K. (et al.) Demokratiya i Federalizm v Rossii. Moskva, Rossiskaya Assotsiatsia Politicheskoi Nauki (RAPN): 193-211.

HEINEMANN-GRÜDER, A. (2007). Ein Schritt vorwärts, zwei zurück. Vom Ethnoföderalismus zum „Russland der Russen“ OSTEUROPA. 57.11: 135-162.

---. (2009) Federal discourses, minority rights, and conflict transformation in: ROSS, C. \& CAMPBELL, A. Federalism and local politics in Russia. London, Routledge: 54-81.

KLISTORIN, V. I. (2011) Sovremennyi Rossiiskii Federalizm: Politicheskie i Fiskal'nye Problemy. Region: Ekonomika i Sotsiologiya. No. 4: 39-50. 
KOLMOGOROVA, D. (2010) Ukrupnenie rossiskikh regionov.. In: BUSYGINOI, I \& HEINEMANN-GRÜDER, A. (et al.) Federalizm i ethnicheskoe raznoobrazie v Rossii, Moscow, Rossiskaya politicheskaya entsiklopediya (ROSSPEN): 149-158.

KONITZER, A. \& WEGREN, S. K. (2006). Federalism and Political Recentralization in the Russian Federation: United Russia As the Party of Power". Publius: The Journal of Federalism. Vol. 36 (4): 503-522.

KOVALEV, V. A. (2007). Federalizm i Rossiiskaya Politika v Ramkakh „Upravlyaemoi Demokratii“ In: KRASIN, Y. A. \& FARUKSHIN, M. K. (et al.) Demokratiya i Federalizm v Rossii. Moskva, Rossiskaya Assotsiatsia Politicheskoi Nauki (RAPN): 234-253.

KYNEV, A. (2010). Rol' gubernatorov v rossiiskoi politicheskoi sisteme. In: BUSYGINOI, I \& HEINEMANN-GRÜDER, A (et al.) Federalizm $i$ ethnicheskoe raznoobrazie $v$ Rossii, Moskva, Rossiskaya politicheskaya entsiklopediya (ROSSPEN):112-134.

LINZ, J. J. \& STEPAN, A. C. (1996). Problems of democratic transition and consolidation: southern Europe, South America, and post-communist Europe. Baltimore, Johns Hopkins University Press.

LUCHTERHANDT, O. (2005) Russland auf dem Weg in den Scheinföderalismus. WOSTOK No. 1: 102-105.

MINDZAEV, M. A. (2011) Evoliutsiya Rossiiskogo Federalizma in MINDZAEV, M. A. Federalizm i Regionalizm: Prioritety XXI Veka. Materialy 3-I Mekhdunarodnoi Nauchnoi Konferentsii. Vladikavkaz: Vladikavkazskii Institut Upravleniya: 20-26.

NUßBERGER, A., \& MARENKOV, D. (2007) Wahlgesetz als Steuerungsmechanismus: Zu den neuen rechtlichen Grundlage der Duma-Wahlen im Dezember 2007 in RUSSLANDANALYSEN No. 146: 2-5.

OVERSLOOT, H. (2009) The Merger of Federal Subjects of the Russian Federation during Putin's Presidency and After. Review of Central and East European Law. Vol. 34.2: 11935.

PETROV, N. (2004) The Security Dimension of the Federal Reforms in: REDDAWAY, P. \& ORTTUNG, R. W. Dynamics of Russian politics: Putin's reform of federal-regional relations. Lanham, Rowman \& Littlefield: 7-32.

REUTER, O. J. /REMINGTON, T. F. (2009) Dominant Party Regimes and the Commitment Problem: The Case of United Russia. In: Comparative Political Studies, Vol. 42/4: 501526.

ROSS, C. (2007) Russia's multinational federation: from constitutional to contract federalism and the 'war of laws and sovereignties'. In: BURGESS, M. \& PINDER, J. Multinational Federations. London, Routledge: 108-127.

SAKWA, R. (2010) Federalism and democracy in the Russian Federation in: BURGESS, M. \& GAGNON, A. Federal democracies. London, Routledge: 202-229.

SNYDER, J. L. (2000) From voting to violence: democratization and nationalist conflict. New York, Norton.

STEPAN, A. (1999) Federalism and Democracy: Beyond the U.S. Model. Journal of Democracy No. 10.4: 19-34.

WATTS, R. L. (2008) Comparing Federal Systems. Montréal, Published for the School of Policy Studies, Queen's University by McGill-Queen's University Press. 
---. (2010) Comparative reflections on federalism and democracy. In: BURGESS, M. \& GAGNON, A. Federal Democracies. London, Routledge: 202-229.

ZAKHAROV, A. (2012) "Cpyashchii Institut”: Federalizm v Sovremennoi Rossii i v Mire. Moskva, Novoe literaturnoe obozrenie.

Internet sources

Case of Republican Party of Russia v. Russia, European Court of Human Rights, 12 April 2011, Final Judgment, http://hudoc.echr.coe.int/sites/eng/pages/search.aspx?i=001-104495 (accessed 5 April 2013)

Earle, J. "Bill to Limit Gubernatorial Elections Approved", 23 January 2013, http://www.themoscowtimes.com/news/article/bill-to-limit-gubernatorial-electionsapproved/474464.html (accessed 30 March 2013).

Kommersant', "Ne nuzhno schitat', chto u nas glupyi narod" №11 (5042), 23.01.2013, http://www.kommersant.ru/doc/2110722 (accessed 5 April 2013).

Petrov, N. "Putin and the Regions", Carnegie Centre, (taken from The Moscow Times), 17 December 2012, http://carnegie.ru/2012/12/17/putin-and-regions/ewet (accessed 29 March 2013).

Petrov, N. "Gubernatorial Election Genie Out of the Bottle", Carnegie Centre, (taken from The Moscow Times), 3 April 2012, http://carnegie.ru/2012/12/17/putin-and-regions/ewet (accessed 29 March 2013)

Rosstat (Federal Service for State Statistics of the Russian Federation) http://www.gks.ru/wps/wcm/connect/rosstat_main/rosstat/ru/statistics/accounts/\# (accessed 2 April 2013).

Winogradow, J./Ostaptschuk, M. "Parteienboom in Russland", Deutsche Welle, 16 February 2013, http://www.dw.de/parteienboom-in-russland/a-16598344?maca=de-newsletter_ostfokus-643-htmlnewsletter (accessed 29 March 2013). 


\section{Annex}

Table 1: Federal mergers

\begin{tabular}{|c|c|c|c|}
\hline $\begin{array}{l}\text { Referendum } \\
\text { Date }\end{array}$ & Merger Date & Merging Subjects & $\begin{array}{l}\text { Newly } \quad \text { Merged } \\
\text { Subject }\end{array}$ \\
\hline 7 Dec. 2003 & 1 Dec. 2005 & $\begin{array}{l}\text { Perm Oblast }+ \text { Komi- } \\
\text { Permyak Autonomous } \\
\text { Okrug }\end{array}$ & Perm Krai \\
\hline 17 April 2005 & 1 January 2007 & $\begin{array}{ll}\text { Krasnoyarsk } & \text { Krai }+ \text { Evenk } \\
\text { Autonomous } & \text { Okrug }+ \\
\text { Taymyr } & \text { Autonomous } \\
\text { Okrug } & \end{array}$ & Krasnoyarsk Krai \\
\hline 23 Oct. 2005 & 1 July 2007 & $\begin{array}{ll}\text { Kamchatka } & \text { Oblast }+ \\
\text { Koryak } & \text { Autonomous } \\
\text { Okrug } & \end{array}$ & Kamchatka Krai \\
\hline 16 April 2006 & 1 January 2008 & $\begin{array}{l}\text { Irkutsk Oblast }+ \text { Ust-Orda } \\
\text { Buryat Autonomous Okrug }\end{array}$ & Irkutsk Oblast \\
\hline 11 March 2007 & 1 March 2008 & $\begin{array}{l}\text { Chita Oblast }+ \text { Agin-Buryat } \\
\text { Autonomous Okrug }\end{array}$ & Zabaikalsky Krai \\
\hline
\end{tabular}

Source: M. Derrick. (2009) The Merging of Russia's Regions as Applied Nationality Policy: A Suggested Rationale. Caucasian Review of International Affairs. Vol. 3 (3): 317-323. 